Revista Eletrônica Geografar, Curitiba, v. 2, Resumos do VI Seminário Interno de Pós-Graduação em Geografia, p. 52-52. Junho/2007

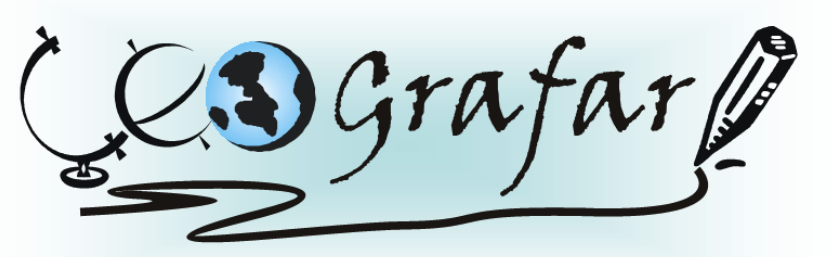

Revista Eletrônica do Programa de Pós-Graduação em Geografia - UFPR

\title{
TERRITÓRIO E TERRITORILIDADES DA IGREJA CATÓLICA ROMANA E DO SAGRADO A PARTIR DO ESPAÇO DE REPRESENTAÇÃO FRANCISCANO DA DIOCESE DE CURITIBA
}

\author{
MARCO AURÉLIO GHISLANDI ${ }^{1}$
}

A partir do Espaço de Representação Franciscano existente na Diocese de Curitiba-PR, o presente trabalho busca propor uma analise do território da Igreja Católica Romana e do Sagrado, bem como de suas supostas territorialidades, tendo como fundamento para as análises a Teoria das Representações Sociais. Com base na obra de Moscovici, o estudo se sustenta na análise do espaço passa a ser entendido como um espaço composto de dois mundos: um mundo dito consensual, próprio das representações, e outro, reconhecido como mundo reificado, próprio das ciências e da política. Neste caso, a Igreja Católica Romana pode ser entendida por meio desta análise. Pois, ao mesmo tempo em que a mesma se projeta como instituição hierarquicamente constituída, também se projeta no espaço como manifestação do Sagrado. No caso específico, uma análise do Espaço de Representação Franciscano, pode revelar que o mesmo se faz como uma extensão do território da Igreja, sendo uma de suas territorialidades, bem como de uma manifestação própria do Sagrado. Portanto, pode-se buscar no espaço de Representação Franciscano um duplo viés de análise. Um que se constitui na Ordem religiosa instituída, a partir do Carisma de Francisco de Assis, transformando-se em extensão da Igreja pela sua subordinação e outro como espaço de manutenção e promoção do próprio carisma de Francisco de Assis. Desta forma, surgem dois mundos, o da instituição propriamente dito, ligado a Igreja através do discurso e outro que se manifesta através da experiência interior dos sujeitos. Um mundo reificado e outro do consensual.

Palavras-chave: Espaço e Representação, Igreja Católica, Sagrado.

${ }^{1}$ Mestrando em Geografia - UFPR - email: feliz_mag@hotmail.com Orientador: SYLVIO FAUSTO GIL FILHO 